\title{
Modelling of Surface Permeation in Multiple-Orifice Permeable Road
}

\author{
Darrien Yau Seng Mah ${ }^{1}$, Siew Ling Loh $^{1}$, Md Abdul Mannan ${ }^{1}$, Wan Hashim Wan Ibrahim ${ }^{1}$ \\ ${ }^{l}$ Department of Civil Engineering, Faculty of Engineering, Universiti Malaysia Sarawak, 94300 Kota Samarahan, Sarawak, Malaysia \\ *Corresponding author E-mail: ysmah@unimas.my
}

\begin{abstract}
A patent-pending StormPav green pavement is introduced here as a form of permeable road, in which the system employed precast concrete pieces as modular units. The pavement layer consists of hexagonal plates with each a service inlet to drain water. This study is exploring the water draining capability or technically surface permeation of these service inlets. Virtual and physical modelling are performed to investigate the service inlets as multiple orifices to permeate surface water of the said permeable road. Both modelling efforts have deduced that the permeable road has $18,000-24,000 \mathrm{~mm} / \mathrm{hr}$ of permeation rate when subjected to a 5-minute red-alert storm $(>60 \mathrm{~mm} / \mathrm{hr}$ of intensity). It implies that StormPav green pavement has superior surface permeation against the forming of water ponding and flash flood on roads.
\end{abstract}

Keywords: CFD; Infiltration; Pavement; Rainfall; Runoff.

\section{Introduction}

The idea of changing the conventional roads to permeable one had been initiated since 1960s. Different permeable road models are introduced since then. For one, this paper introduces a new form of permeable road - a patent-pending Industrialized Building System (IBS) product named StormPav [1] (see Figure 1).

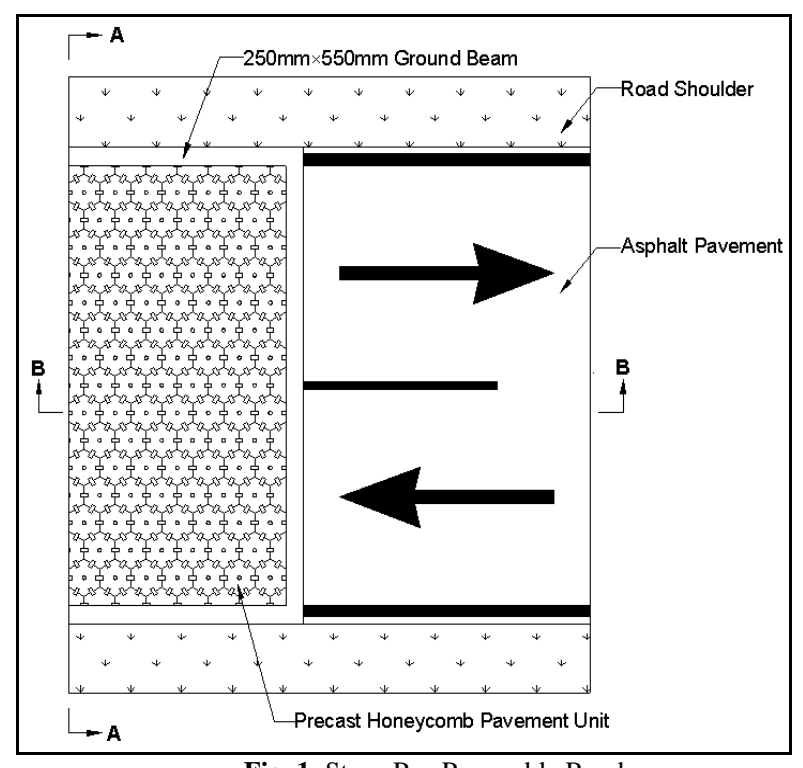

Fig. 1: StormPav Permeable Road

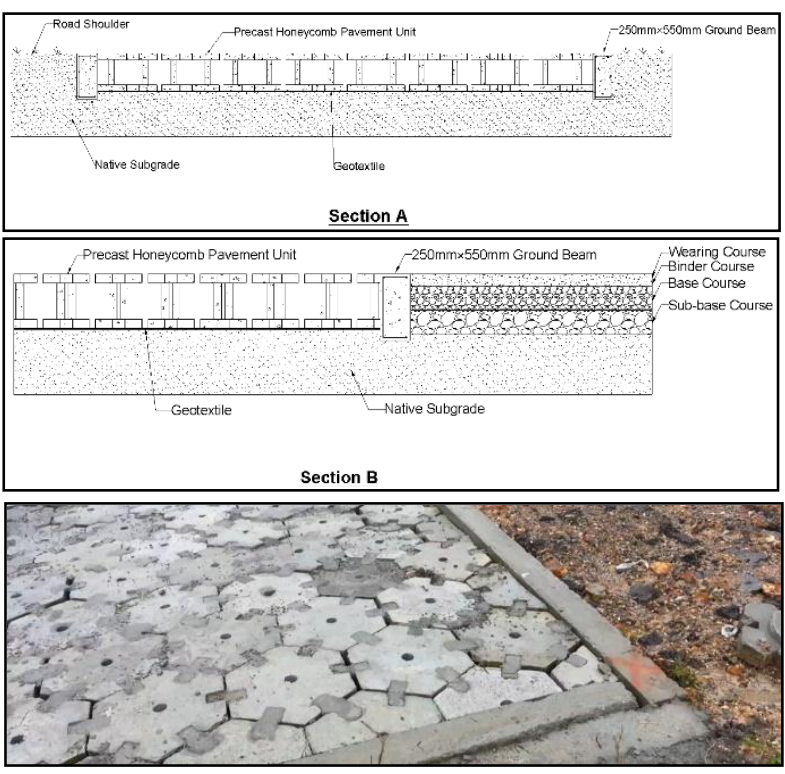

Fig. 1: Continued

StormPav consists of three precast concrete pieces to form a single modular unit, namely a top cover, a cylinder and a bottom plate (see Figure 2). Specially designed Grade 50 concrete mix is used to cast these pieces that could withstand crushing load up to 100 $\mathrm{kN} / \mathrm{unit}$. Utilization of the specialist concrete with high loading capacity has enable the fabrication of such a IBS modular unit. It has been designed to have hollow cylinders as the middle layer that function as temporary stormwater storage; and even with the intentional cavity, a single modular unit is proven strong enough in the laboratory to withstand heavy vehicle on top of it [2-3]. 


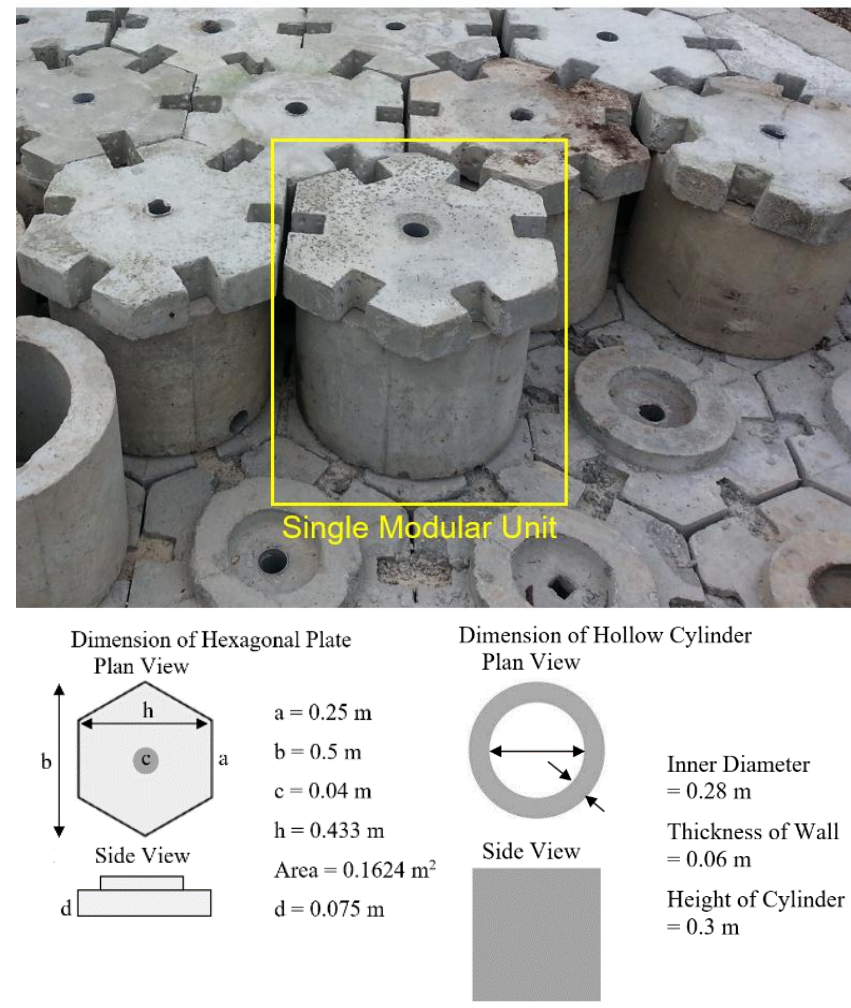

Fig. 2: Dimensions of StormPav modular unit

The modular units could hold water $0.19 \mathrm{~m}^{3} / \mathrm{m}^{2}$ of pavement area [4]; in another word, fully capture 3-hour continuous 10-year Average Recurrent Interval (ARI) design storm. In the series of reporting findings of StormPav, an investigation is presented here about the capacity of the service inlet on the top cover to drain water.

\section{Surface Permeation}

Hypothetically, stormwater could be penetrated to underground storage through internal voids or spaces that are provided on the road pavement. The presence of these opening cells is significant to make the pavement permeable. Basically, surface permeation of permeable pavement works according to the principle of capillary action, where the water seeps through the narrow spaces of interconnected voids. The term could be defined as "a measure of the water flow through the pore spaces or fractures" in the permeable medium [5].

As stated by [6], the performance of permeable pavement is prominently dependent on the void content of the pavement type. Take permeable concrete as an example, the void content is usually ranging from $15 \%$ to $35 \%$ of the concrete mix [7]. Another example, typical void content of permeable asphalt is almost the same as the former, at least $16 \%$ of air void content is specified to the total mix volume [8].

The higher the void content, the higher the surface permeation of permeable pavement. Yet the trend of surface permeation is also adversely affecting the strength of pavement. As a reference point, the design of permeable pavement should meet the requirements that are recommended by the local authority. As tabulated in Table 1 , recommended values of surface permeation for permeable pavement are varied in different countries.

Table 1: Recommendations of surface permeation for permeable pavement

\begin{tabular}{ll}
\hline \multicolumn{1}{c}{ Source } & $\begin{array}{l}\text { Recommended Values for Surface Permea- } \\
\text { tion }\end{array}$ \\
\hline $\begin{array}{l}\text { ASLA } \\
\text { Credit Valley Conserva- }\end{array}$ & $\begin{array}{l}140+\mathrm{in} / \mathrm{hr}(3,500+\mathrm{mm} / \mathrm{hr}) \\
\text { tion }^{2}\end{array}$ \\
United Kingdom $^{3}$ & $600-21,500 \mathrm{~mm} / \mathrm{hr}$ \\
\end{tabular}

Malaysia $^{4}$

For highest rainfall intensity of $598.9 \mathrm{~mm} / \mathrm{hr}$, average 4.2 minutes per $10 \mathrm{~cm}$ depth (1430 $\mathrm{mm} / \mathrm{hr}$ );

For lowest rainfall intensity of $12.4 \mathrm{~mm} / \mathrm{hr}$, average 4.3 hours per $10 \mathrm{~cm}$ depth $(24$ $\mathrm{mm} / \mathrm{hr})$.

Note:

${ }^{1}$ American Society of Landscape Architect

${ }^{2}$ Toronto and Region Conservation, Canada, http://creditvalleyca.ca

${ }^{3}$ Institute for Infrastructure and Environment, Heriot-Watt University, UK

${ }^{4}$ School of Civil Engineering, Universiti Sains Malaysia [9]

\section{Motivation}

The service inlet on the StormPav top cover is a $40 \mathrm{~mm}$ circular opening for surface permeation. Contrary to those in previous section, StormPav uses the principle of orifice flow that is significantly different than the former. This is the research gap for such a type of permeable pavement. When these top covers are assembled together, they form a flat surface with many holes that allow surface permeation to the underground storage. As such, it can be said that the interlocked top covers function as a multiple-orifice plate, which poses a discharge rate to the system to drain stormwater.

Industrial multiple-orifice plates are manufactured following the pipeline sizes. As illustrated in Figure 3, the volumetric flow rate per orifice (on the left) equals with each other, if they have a similar geometry and cross-sectional area [10-12].
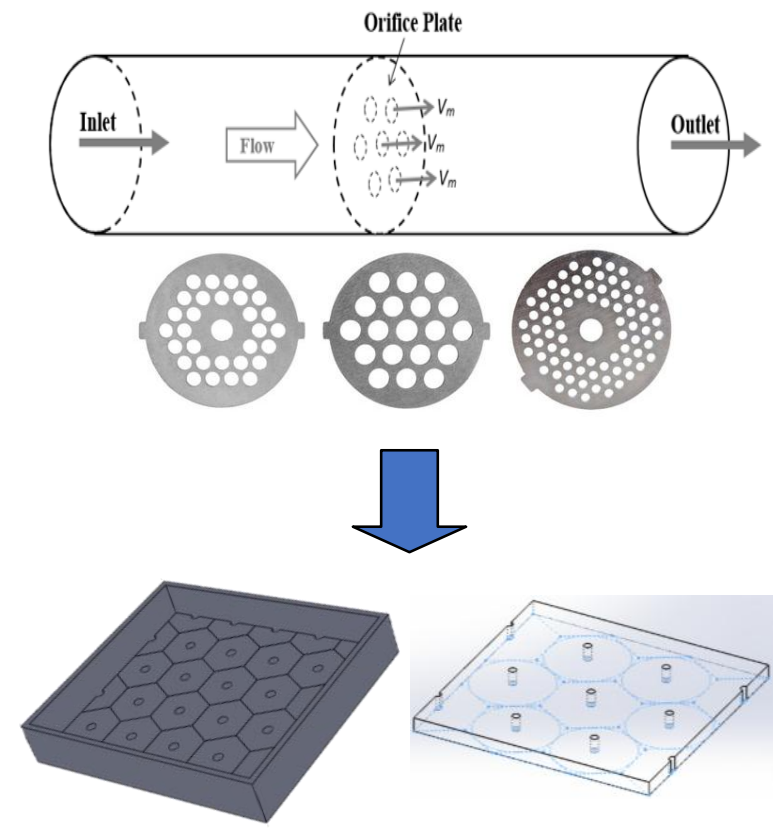

Fig. 3: Approach to surface permeation

However, the StormPav top covers (at the bottom of Figure 3) are demonstrating a trait peculiar to industrial orifice plates. As the number of orifice increases, the size of its surface area also increases, in which this could never happen in the pipeline industry to accommodate ever increasing pipeline sizes. In another word, the StormPav top covers present a case of unprecedented use of multiple-orifice plate that the existing formula may require modification. Therefore, it is reasonable to prescribe virtual and physical modelling to serve as a basis to understand orifice flow for such a new system.

\section{Virtual Modelling}

To accommodate virtual modelling of orifice flow, Computational Flow Dynamic (CFD) technique is applied to represent the Storm- 
Pav system. The road surface and road kerb are modelled as a "big" rectangular pipe that flows vertically downward through an orifice plate (see Figure 4).

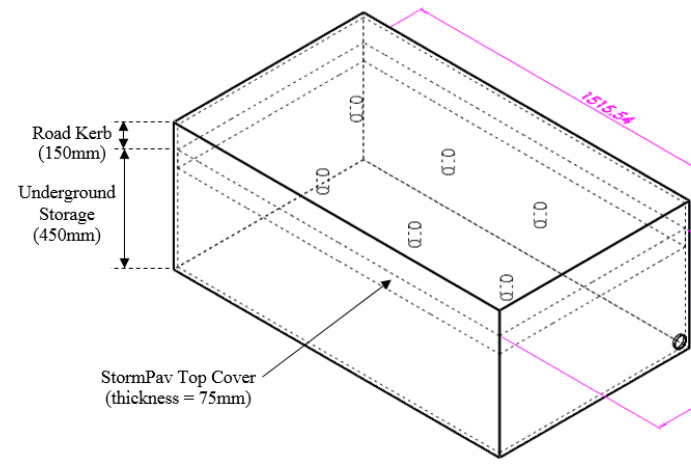

Fig. 4: CFD model of StormPav permeable road

For normal practice, 15-minute, 10-year ARI design rainfall is used for urban built environment. In this regard, the local weather data has it derived an intensity of $180 \mathrm{~mm} / \mathrm{hr}$. To make a realistic representation of rainfall, the 15-minute design storm is divided equally into three blocks of time period. Rainfall intensities of $57.6 \mathrm{~mm} / \mathrm{hr}, 90.0 \mathrm{~mm} / \mathrm{hr}$ and $32.4 \mathrm{~mm} / \mathrm{hr}$ are obtained accordingly. By doing so, three types of flow are computed as $0.02 \mathrm{l} / \mathrm{s}, 0.03 \mathrm{l} / \mathrm{s}$ and $0.01 \mathrm{l} / \mathrm{s}$ (see Table 2) respectively to be fed to both CFD simulation and laboratory testing for analysis.

\begin{tabular}{|c|c|c|c|}
\hline \multirow{2}{*}{$\begin{array}{l}\text { Time } \\
\text { Block }\end{array}$} & \multirow{2}{*}{$\begin{array}{l}\text { Rainfall } \\
\text { Intensity } \\
(\mathbf{m m} / \mathbf{h r})\end{array}$} & \multicolumn{2}{|l|}{ Flow } \\
\hline & & Computational Step $\left(\mathrm{m}^{3} / \mathrm{s}\right)$ * & $(\mathrm{l} / \mathrm{s})$ \\
\hline $\begin{array}{c}1 \\
(0-5 \\
\min )\end{array}$ & 57.6 & $\begin{array}{l}\mathrm{Q}_{1}=\mathrm{IA} / 3600 \\
=[(57.6 / 1000) \times(0.875 \times 1.515)] / 3600 \\
=2.12 \times 10^{-5}\end{array}$ & 0.02 \\
\hline $\begin{array}{c}2 \\
(5-10 \\
\min )\end{array}$ & 90.0 & $\begin{array}{l}\mathrm{Q}_{2}=\mathrm{IA} / 3600 \\
=[(90.0 / 1000) \times(0.875 \times 1.515)] / 3600 \\
=3.31 \times 10^{-5}\end{array}$ & 0.03 \\
\hline $\begin{array}{c}3 \\
(10-15 \\
\min )\end{array}$ & 32.4 & $\begin{array}{l}\mathrm{Q}_{3}=\mathrm{IA} / 3600 \\
=[(32.4 / 1000) \times(0.875 \times 1.515)] / 3600 \\
=1.19 \times 10^{-5} \\
\text { * By using Rational Formula } \\
\mathrm{Q}=\mathrm{IA} / 3600 \\
\text { where } \mathrm{I}=\text { rainfall intensity (in } \mathrm{m} / \mathrm{hr}) \\
\quad \mathrm{A}=\text { =area intercepting the rainfall } \\
\quad\left(\mathrm{in} \mathrm{m}^{2}\right)\end{array}$ & 0.01 \\
\hline
\end{tabular}

By using SolidWorks, the flows of $0.01 \mathrm{l} / \mathrm{s}, 0.02 \mathrm{l} / \mathrm{s}$ and $0.03 \mathrm{l} / \mathrm{s}$ are uniformly distributed through a $150 \mathrm{~mm}$ high road kerb to the orifice plate. Surface permeations through the orifice plate are found to be consistent with the theory, i.e. the rate equals with each other (see Figure 5).
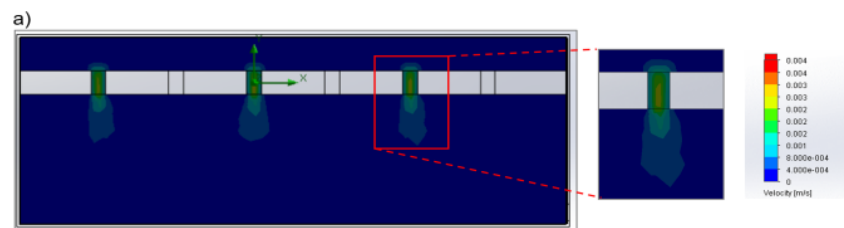

b)
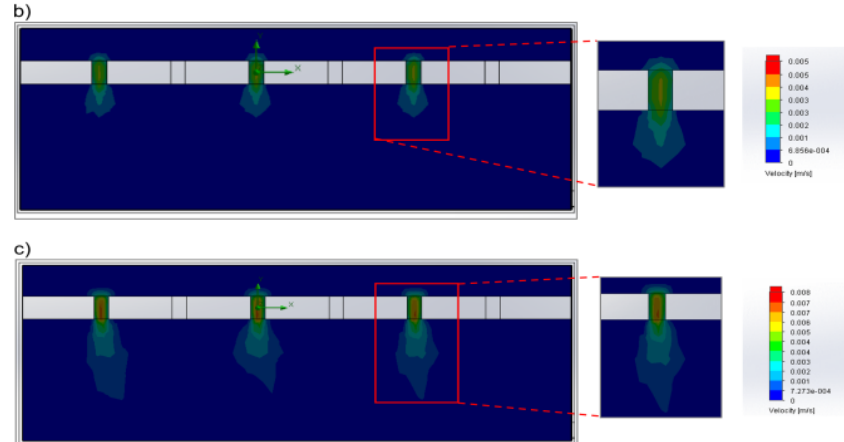

Fig. 5: Velocity profile through service inlet for flows a) $0.01 \mathrm{1} / \mathrm{s}, \mathrm{b}$ ) 0.02 $1 / \mathrm{s}$ and c) $0.031 / \mathrm{s}$
CFD simulations show that the surface permeation increases when the flow passing through increases. The efforts have estimated maximum velocities of $0.0025 \mathrm{~m} / \mathrm{s}, 0.0036 \mathrm{~m} / \mathrm{s}$ and $0.0067 \mathrm{~m} / \mathrm{s}$ respectively; after being converted, they stand for $9,000 \mathrm{~mm} / \mathrm{hr}$, $12,960 \mathrm{~mm} / \mathrm{hr}$ and $24,120 \mathrm{~mm} / \mathrm{hr}$ through the orifice plate - a range more superior than any of those highlighted in Table 1.

\section{Physical Modelling}

In order to verify the CFD simulations, a laboratory testing is carried out. StormPav modular units are placed within a water tank of L1.67m x W1.09m x H0.60m (see Figure 6). Only six (6) full top covers could fit into the tank (Figure 6a), together with two (2) half covers and eight (8) triangular side covers. This justifies the size used in the CFD simulations earlier.

The half and side plates are substituted with acrylic plates, bounded by another four (4) large acrylic plates at four sides to envelope the modular units and to represent road kerb. Gaps between the modular units are sealed with sealant and covered with duct tapes. Careful sealing at the sides is to ensure no water to seep through any spaces other than the six (6) service inlets (Figure 6b). Note that the CFD model only simulates six service inlets to be in line with this laboratory setting.

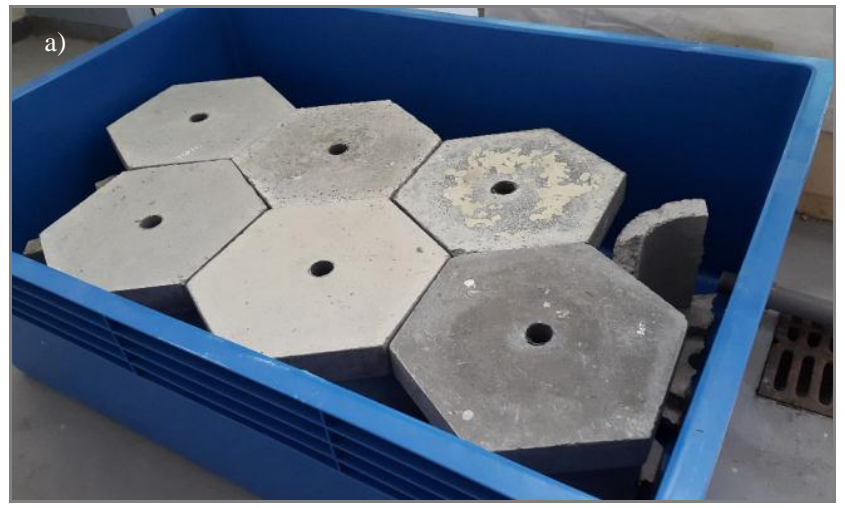

Fig. 6: Laboratory settings, a) Interlocking hexagonal plates, b) Rainfall simulator placed on top Of hexagonal plates, and c) Water dripping from rainfall simulator
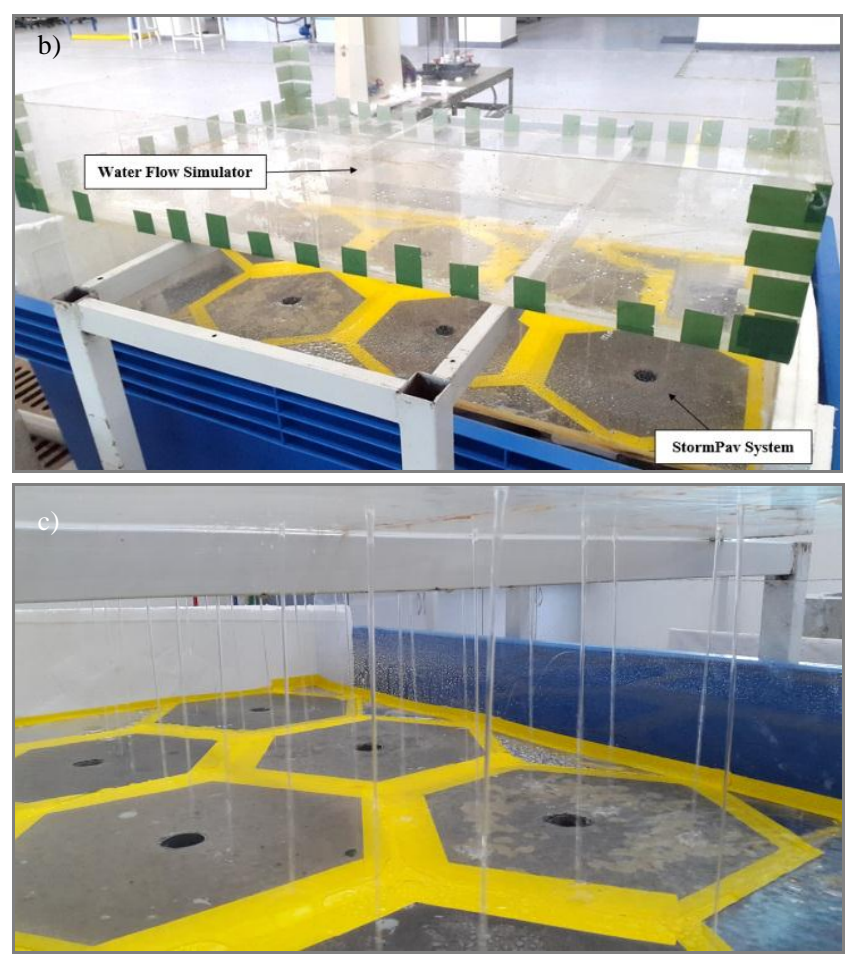

Fig. 6: Continued 
A non-pressurized rainfall simulator is created with a smaller tank of $\mathrm{L} 1.50 \mathrm{~m} \times \mathrm{W} 1.00 \mathrm{~m} \times \mathrm{H} 0.24 \mathrm{~m}$ on top of the modular units. 2 mm diameter opening are drilled on the bottom of this tank. In order to simulate various rainfall intensities, the flow rate of the simulator is controlled by selectively closing the openings (visible on the top of Figure 6c). As a result, it is discovered that the increasing number of openings allowed the water to drain faster from the simulator tank and thus, a shorter time is required for a higher flow rate.

Twelve (12) openings over 51 of water are adequate to simulate an intensity of $35 \mathrm{~mm} / \mathrm{hr}$; twenty (20) openings for $57 \mathrm{~mm} / \mathrm{hr}$; and thirty (30) openings for $90 \mathrm{~mm} / \mathrm{hr}$. Surface permeation processes of the service inlets are observed. Average velocities of 0.0021 $\mathrm{m} / \mathrm{s}, 0.0030 \mathrm{~m} / \mathrm{s}$ and $0.0051 \mathrm{~m} / \mathrm{s}$ are recorded; after being converted, they stand for $7,560 \mathrm{~mm} / \mathrm{hr}, 10,800 \mathrm{~mm} / \mathrm{hr}$ and $18,360 \mathrm{~mm} / \mathrm{hr}$ through the service inlets.

\section{Discussion}

Both CFD simulations and laboratory testing show that the orifice flow is highly dependent on rainfall intensity. The more runoff is generated, the more surface permeation is through the orifices. However, the values of simulation results are found to be larger than laboratory tests. For example, CFD result shows that each service inlet has the highest surface permeation of $24120 \mathrm{~mm} / \mathrm{hr}$ (by converting the obtained velocity) at an inflow rate of $0.03 \mathrm{1} / \mathrm{s}$, while the average value of laboratory tests is $31 \%$ lesser than that. Similarly, the surface permeation values obtained in the laboratory tests are 19\% lower than CFD data for both inflow rates of $0.01 \mathrm{l} / \mathrm{s}$ and $0.02 \mathrm{l} / \mathrm{s}$ in Table 3.

In this regard, CFD simulations analyse the model as a full flow system in which the orifices are full of stormwater. Bear in mind that the CFD is taking the StormPav system as a rectangular pipe flow. As illustrated in Figure 5, this phenomenon can be seen in the simulation results as there are three (3) water ponding scenarios to enable the stormwater to have a full flow in all orifices. However, water ponding is not observed in the laboratory testing as the stormwater permeates into the underground chambers through the edges of orifices. As demonstrated in Figure 6, rainfall simulator in the laboratory testing is using the dripping method. As volume of water on the pavement surface is more critical to represent the surface runoff than the rain drop sizes, this method is appropriate.

Table 3: Comparisons of surface permeation

\begin{tabular}{ccc}
\hline \multirow{2}{*}{$\begin{array}{c}\text { Rainfall Intensity } \\
(\mathbf{m m} / \mathbf{h r})\end{array}$} & \multicolumn{2}{c}{ CFD Simulation } \\
\cline { 2 - 3 } & $(\mathbf{m} / \mathbf{s})$ & $(\mathbf{m m} / \mathbf{h r})$ \\
\hline 32.4 & 0.0025 & 9000 \\
57.6 & 0.0036 & 15840 \\
90.0 & 0.0067 & 24120 \\
\hline
\end{tabular}

\begin{tabular}{|c|c|c|c|c|c|c|}
\hline \multirow{3}{*}{$\begin{array}{l}\text { Rainfall } \\
\text { Intensity } \\
(\mathbf{m m} / \mathbf{h r})\end{array}$} & \multicolumn{5}{|c|}{ Laboratory Testing } & \multirow{3}{*}{$\begin{array}{c}\text { Difference } \\
(\%)\end{array}$} \\
\hline & \multirow{2}{*}{$\begin{array}{c}1 \\
(\mathrm{~m} / \mathrm{s})\end{array}$} & \multirow{2}{*}{$\begin{array}{c}2 \\
(\mathrm{~m} / \mathrm{s})\end{array}$} & \multirow{2}{*}{$\begin{array}{c}3 \\
(\mathbf{m} / \mathbf{s})\end{array}$} & \multicolumn{2}{|c|}{ Average } & \\
\hline & & & & $(\mathrm{m} / \mathrm{s})$ & $(\mathrm{mm} / \mathrm{hr})$ & \\
\hline 35 & 0.0021 & 0.0020 & 0.0023 & 0.0021 & 7560 & -19 \\
\hline 55 & 0.0037 & 0.0038 & 0.0036 & 0.0037 & 13320 & -19 \\
\hline 90 & 0.0050 & 0.0048 & 0.0053 & 0.0051 & 18360 & -31 \\
\hline
\end{tabular}

As such, the authors identify a limitation of the CFD simulation of flow through StormPav system. Surface permeations by CFD are 19 - 31\% higher compared to the laboratory testing. In fact, CFD has a constraint in simulating flow only at the edges of orifices. Having said so, it is common in flow modelling of environmental systems that a correlation of 0.6 is acceptable when comparing the modelled and observed hydrographs (for example in the engineering manual of US Army Corps of Engineers), in which a difference of up to $40 \%$ is accepted due to complexity in the actual environmental processes. Based on the mentioned precedence, the difference of up to $31 \%$ demonstrated in the CFD could be taken as acceptable as well.

\section{Conclusion}

There are significant differences between the CFD simulations and laboratory testing, as high as $31 \%$. In the absence of better computer modelling technique, the employed applied methods could not provide a solution to improve the existing formula of multipleorifice plate to accommodate StormPav road. Yet, both efforts have shown that the multiple-orifice permeable road has a superior quality in surface permeation and an estimation of $18,000-$ $24,000 \mathrm{~mm} / \mathrm{hr}$ has been derived.

\section{Acknowledgement}

This project was funded by Universiti Malaysia Sarawak via Special Top Down Grant F02/SpTDG/1440/16/3.

\section{References}

[1] Mannan MA, Bateni N, Teo DCL, Mah YS, Putuhena FJ, Ng CK, Bustami RA, Ibrahim WHW, Lee CLF, Lim HL (2016), StormPav System and Method of Green Pavement. MyIPO PI2016704420, Kuala Lumpur, Malaysia.

[2] Mah DYS, Putuhena FJ, Rosli NA (2014), Environmental technology: Potential of merging road pavement with stormwater detention. Journal of Applied Science \& Process Engineering 1(1), 1-8.

[3] Mah DYS (2016), Potential of Road Subsurface On-Site Stormwater Detention System. ISBN 978-969-2008-05-7. Universiti Malaysia Sarawak Publisher, Kota Samarahan, Sarawak, Malaysia.

[4] Ngu JOK, Mah DYS, Bong CHJ (2016), Flow characteristics of individual lot stormwater detention. Water Practice and Technology 11(4), 721-727. DOI: 10.2166/wpt.2016.079.

[5] Ong SK, Wang K, Ling Y, Shi GY (2016), Pervious Concrete Physical Characteristics and Effectiveness in Stormwater Pollution Reduction. Institute for Transportation, Iowa State University, Ames, Iowa, US.

[6] Park DG, Sandoval N, Lin W, Kim H, Cho YH (2014), A case study: evaluation of water storage capacity in permeable block pavement. Korean Society of Civil Engineers (KSCE) Journal of Civil Engineering 18(2), 514-520.

[7] Teraiya D, Doshi U, Viradiya P, Yagnik A, Joshi T (2015), To develop method to find out permeability and void ratio for pervious concrete. International Journal of Research in Engineering and Technology 4(13), 177-182.

[8] Hansen K (2008), Information Series 131 Porous Asphalt Pavements for Stormwater Management; Design, Construction and Maintenance Guide. National Asphalt Pavement Association (NAPA), Lanham, Maryland, US.

[9] Hamzah MO, Jaafar ZFM, Ahmad F (2013), Laboratory simulation of porous asphalt parking lot system and mix design for storm water management. Journal of Engineering Science and Technology 8(2), 217-232.

[10] Shah MS, Joshi JB, Kalsi AS, Prasad CSR, Shukla DS (2012), Analysis of flow through an orifice meter: CFD simulation. Chemical Engineering Science 71, 300-309.

[11] Barki M, Ganesha T, Math MC (2014), CFD analysis and comparison of fluid flow through a single hole and multi hole orifice plate. International Journal of Research in Advent Technology 2(8), 6-15.

[12] Singh VK, Tharakan TJ (2015), Numerical simulations for multihole orifice flow meter. Flow Measurement and Instrumentation 45 375-383. 